\title{
Population genetics and ecology of Sumatran camphor (Dryobalanops aromatica) in natural and community-owned forests in Indonesia
}

\author{
FAUJIAH NURHASANAH RITONGA ${ }^{1, v}$, FIFI GUS DWIYANTI ${ }^{2,3}$, CECEP KUSMANA $^{2}$, \\ ULFAH JUNIARTI SIREGAR ${ }^{2}$, ISKANDAR ZULKARNAEN SIREGAR, ${ }^{2, \bullet}$ \\ ${ }^{1}$ Graduate Study Program of Tropical Silviculture, Institut Pertanian Bogor. Jl. Raya Dramaga, Bogor 16680, West Java, Indonesia. \\ Tel.: +62-251-8626806, Fax.: +62-251-8626886, "email: ritongafaujiah@ymail.com \\ ${ }^{2}$ Department of Silviculture, Faculty of Forestry, Institut Pertanian Bogor. Jl. Raya Dramaga, Bogor 16680, West Java, Indonesia.

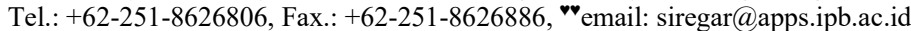 \\ ${ }^{3}$ Directorate of International Program, Institut Pertanian Bogor. Andi Hakim Nasoetion Bldg. ${ }^{\text {st }}$ Floor, Jl. Raya Dramaga, Bogor 16680, West Java, \\ Indonesia
}

Manuscript received: 3 August 2018. Revision accepted: 4 November 2018.

\begin{abstract}
Ritonga FN, Dwiyanti FG, Kusmana C, Siregar UJ, Siregar IZ. 2018. Population genetics and ecology of Sumatran camphor (Dryobalanops aromatica) in natural and community-owned forests in Indonesia. Biodiversitas 19: 2175-2182. Dryobalanops aromatica Gaertn. f. (Sumatran camphor) is a valuable tree species that produces borneol (camphor) and good-quality timber. However, the population of this species has declined due to illegal logging and conversion of forests into plantations and has been classified as Critically Endangered by the International Union for Conservation of Nature. This study aimed to examine the genetic variation and spatial distribution of this species in a community-owned forest (Barus) and two natural forests (Singkohor and Danau Paris) in Indonesia using the Random Amplified Polymorphic DNA marker. The results of this study showed that D. aromatica had moderate levels of genetic variation (expected heterozygosity [He] $=0.1760$ [Barus population] to 0.2134 [Singkohor population]) and genetic differentiation (Nei's Gst $=0.1257$ ). The genetic distance was the smallest between the Singkohor and Danau Paris populations (Nei's distance $=0.0363$ ) and greatest between the Singkohor and Barus populations (Nei's distance $=0.0534$ ). The spatial distribution of $D$. aromatica was grouped in both Barus and Danau Paris based on Morisita's index of diversity (ip $=0.06$ and 0.043 , respectively). These findings indicated that genetic conservation might be performed in situ in combination with enrichment planting using locally propagated sources.
\end{abstract}

Keywords: Conservation, Dryobalanops aromatica, genetic variation, RAPD, spatial distribution

\section{INTRODUCTION}

Dryobalanops aromatica Gaertn. f. (Sumatran camphor) is a valuable tree species that produces borneol (camphor) in the form of crystals and oil, which contains bioactive compounds that have antioxidant, antifungal, and cytotoxic effects and can even counteract the spread of human immunodeficiency virus (Wibowo et al. 2011). However, populations of $D$. aromatica are declining as a result of deforestation, forest fires, and conversion of forests into oil palm (Elaeis guineensis) plantations (Gusmailina 2014). This species is now being considered as a rare plant in Indonesia, particularly in Central Tapanuli and Aceh Singkil Regencies and categorized as Critically Endangered by the International Union for Conservation of Nature (Dwiyanti et al. 2014; Gusmailina 2014). Consequently, it is crucial that populations of $D$. aromatica are conserved and supplemented through propagation. In Central Tapanuli, D. aromatica is being conserved through the development of community-owned forests. Such ex-situ conservation requires the population size to be sufficiently large to ensure genetic diversity within each population and reduce the chances of inbreeding, which will reduce the genetic diversity (Nguyen et al. 2014). However, only a small population is being maintained because of commercial plantations, mainly oil palm plantations, offering greater economic opportunities for the local people. In addition, there is a lack of information on the genetic diversity and structure of the species in this area, which is a fundamental requirement for the development of appropriate conservation strategy and sustainable forestry management (Tsumura 2011; Dwiyanti et al. 2015).

One of the molecular markers that can be used to determine genetic diversity within and between populations is the Random Amplified Polymorphic DNA (RAPD). The main advantages of this marker are that it produces sufficiently high levels of polymorphism, randomly samples the whole genome, and is technically relatively quick and easy to perform (Yulita and Partomihardjo 2011). The results can then be used in combination with various additional data to determine the overall status of the genetic diversity of a species (Kaur et al. 1978). Such data can include the ecological characteristics of a species such as its structure and composition, which can be determined through vegetation analysis. Therefore, this study was aimed to assess the genetic diversity and spatial distribution of $D$. aromatica in Central Tapanuli and Aceh Singkil Regencies to help formulate the most appropriate strategy for its genetic conservation. We believe that the findings of this study will help to conserve this critically 
endangered plant through both in situ and ex situ conservation strategy.

\section{MATERIALS AND METHODS}

\section{Study site}

This study was conducted between October 2015 and May 2016. Leaves and field data were collected from a community-owned forest in Barus Sub-district, Central Tapanuli District, North Sumatra Province $\left(02^{\circ} 04^{\prime} 17.9^{\prime \prime} \mathrm{N}\right.$, $\left.98^{\circ} 21^{\prime} 32.1^{\prime \prime} \mathrm{E}\right)$ and two natural forests in Aceh Singkil District, Nanggroe Aceh Darussalam Province (Singkohor, $02^{\circ} 30^{\prime} 24.2^{\prime \prime} \mathrm{N}$, 97 $58^{\prime} 23.4^{\prime \prime} \mathrm{E}$, and Danau Paris, $02^{\circ} 19^{\prime} 10.9^{\prime \prime} \mathrm{N}, 98^{\circ} 08^{\prime} 25.7^{\prime \prime} \mathrm{E}$ ) (Figure 1). DNA extraction and RAPD analysis were carried out in the Laboratory of Forest Genetics and Molecular Forestry, Department of Silviculture, Faculty of Forestry, Bogor Agricultural University (IPB), Bogor, Indonesia.

\section{Leaf morphological variation analysis}

Leaves were sampled for morphological variation analysis according to the methods by Kremer et al. (2002) and Anwar (2015) with some modifications in which sinus width (SW) of the leave were not measured due to the differences in the leave form. One branch bearing at least five leaves were collected from each tree, and the following measurements were taken for each leaf: lamina length (LL), petiole length (PL), lobe width (LW), length of lamina at the widest part (WP), number of secondary veins (NSV), an angle between the primary and secondary veins $(\mathrm{AV})$. The measured leaf variables were then used to calculate the leaf area (LA) and circumference of leaves $(\mathrm{CL})$, aspect ratio (AR), form factor (FF) and perimeter ratio of diameter (PR) according to the methods by $\mathrm{Wu}$ et al. (2007) and Anwar et al. (2015). These data were then compared among populations using t-tests in Minitab version 16 (Minitab 2010).

\section{Genetic variation analysis}

About 7-30 young leaf samples were collected from each site for DNA analysis. DNA extraction was carried out using the cetyltrimethylammonium bromide (CTAB) method (Weising et al. 2005; Aritonang et al. 2007), and the quality of the extracted DNA was determined by agarose gel electrophoresis, soaking the gel in a solution of ethidium bromide for $15 \mathrm{~min}$, and photographing it on a TFX-20.LM model UV transilluminator (Suharsono and Utut 2012).
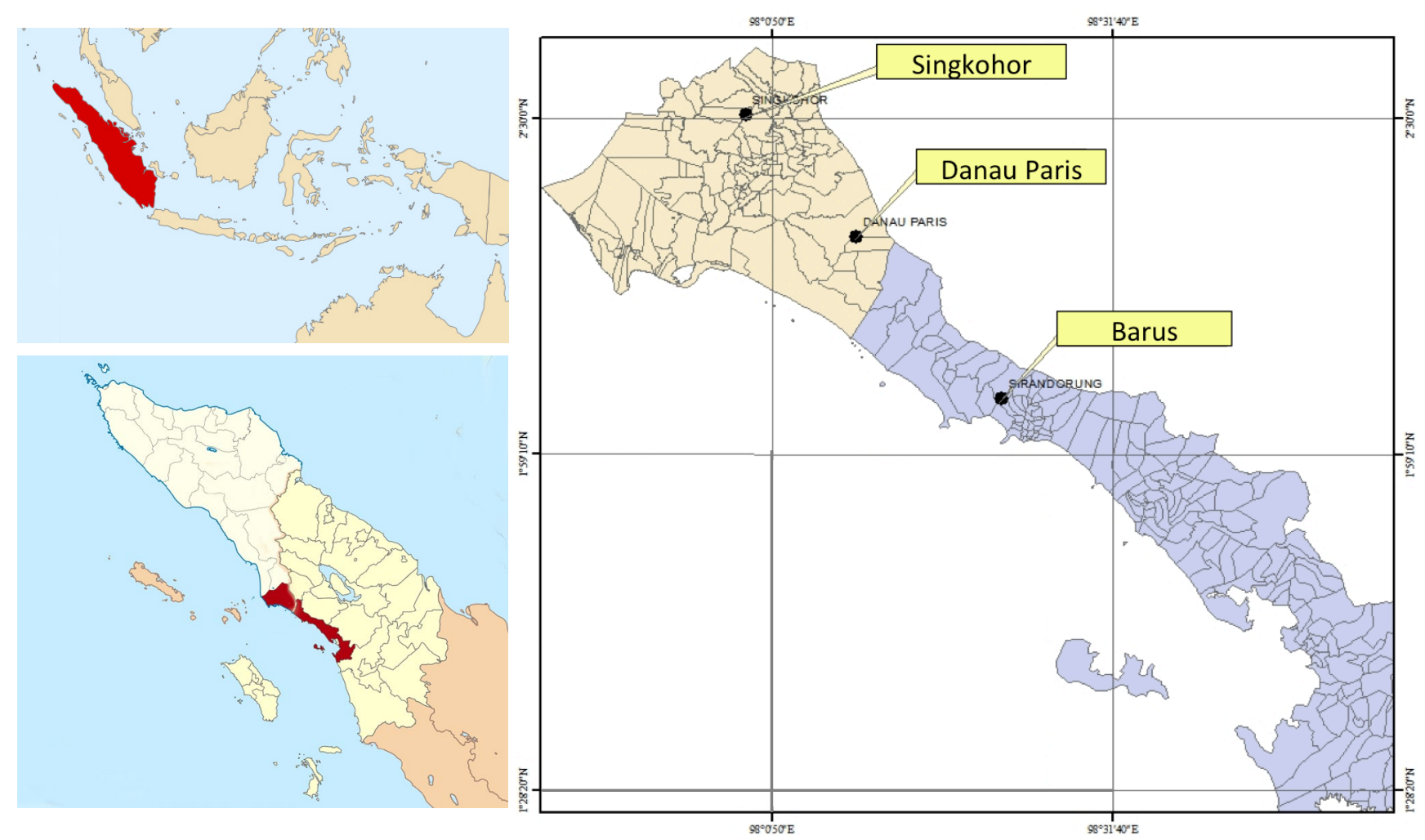

Figure 1. Location of the three Dryobalanops aromatica populations examined in this study 
Table 1. RAPD sequence primers used in this study (Lee et al. 1999; Yulita and Partomihardjo 2011)

\begin{tabular}{llccc}
\hline Locus & $\begin{array}{l}\text { Sequence } \\
\text { primer }\left(\mathbf{5}^{\prime}-\mathbf{3}^{\prime}\right)\end{array}$ & $\left.\mathbf{T}_{\mathbf{m}} \mathbf{(}^{\mathbf{}} \mathbf{C}\right)$ & $\begin{array}{c}\text { Expected } \\
\text { size }(\mathbf{b p})\end{array}$ & $\begin{array}{c}\text { Number of } \\
\text { polymorphic } \\
\text { loci }\end{array}$ \\
\hline OPA-09 & GGGTAACGCC & $32-38$ & $250-1100$ & 15 \\
OPB-08 & GTCCACACGG & $32-38$ & $250-1050$ & 12 \\
OPB-16 & TTTGCCCGGA & $32-38$ & $250-1200$ & 13 \\
OPB-20 & GGACCCTTAC & $32-38$ & $300-1250$ & 8 \\
OPP-09 & GTGGTCCGCA & $32-38$ & $250-1150$ & 7 \\
OPP-10 & TCCCGCCTAC & $32-38$ & $300-1100$ & 11 \\
OPP-14 & CCAGCCGAAC & $32-38$ & $250-900$ & 12 \\
OPP-15 & GGAAGCCAAC & $32-38$ & $250-1000$ & 9 \\
OPP-19 & GGGAAGGACA & $32-38$ & $200-1050$ & 10 \\
OPC-07 & GTCCCGACGA & $32-38$ & $350-1450$ & 11 \\
\hline
\end{tabular}

Table 2. Morphological traits of Dryobalanops aromatica leaves at the Danau Paris and Barus study sites

\begin{tabular}{|c|c|c|c|c|}
\hline \multirow{2}{*}{$\begin{array}{l}\text { Leaf } \\
\text { morphological } \\
\text { traits }\end{array}$} & \multicolumn{4}{|c|}{ Site } \\
\hline & Danau Paris & CV (\%) & Barus & CV $(\%)$ \\
\hline $\mathrm{LL}(\mathrm{cm})$ & $9.52 \pm 1.55^{\mathrm{a}}$ & $6.14^{\mathrm{L}}$ & $10.59 \pm 1.27^{\mathrm{b}}$ & $8.33^{\mathrm{L}}$ \\
\hline $\mathrm{PL}(\mathrm{cm})$ & $0.94 \pm 0.14^{\mathrm{a}}$ & $6.71^{\mathrm{L}}$ & $0.756 \pm 0.23^{b}$ & $3.28^{\mathrm{L}}$ \\
\hline $\mathrm{LW}(\mathrm{cm})$ & $4.18 \pm 0.49^{\mathrm{a}}$ & $8.53^{\mathrm{L}}$ & $4.53 \pm 0.4^{b}$ & $8.39^{\mathrm{L}}$ \\
\hline $\mathrm{WP}(\mathrm{cm})$ & $3.76 \pm 0.61^{\mathrm{a}}$ & $6.16^{\mathrm{L}}$ & $4.37 \pm 0.59^{b}$ & $7.40^{\mathrm{L}}$ \\
\hline NSV & $73.0 \pm 12.5^{\mathrm{a}}$ & $5.84^{\mathrm{L}}$ & $68.1 \pm 12.6^{\mathrm{a}}$ & $5.40^{\mathrm{L}}$ \\
\hline $\operatorname{AV}\left({ }^{\circ}\right)$ & $74.12 \pm 5.24^{\mathrm{a}}$ & $14,15^{\mathrm{L}}$ & $72.52 \pm 3.53^{\mathrm{a}}$ & $20.54^{\mathrm{H}}$ \\
\hline LA (cm) & $126.0 \pm 26.5^{\mathrm{a}}$ & $4.75^{\mathrm{L}}$ & $152.5 \pm 31.6^{\mathrm{b}}$ & $4.83^{\mathrm{L}}$ \\
\hline CL (cm) & $43.52 \pm 5.40^{\mathrm{a}}$ & $8.05^{\mathrm{L}}$ & $48.0 \pm 5.20^{\mathrm{b}}$ & $9.23^{\mathrm{L}}$ \\
\hline AR & $2.29 \pm 0.48^{\mathrm{a}}$ & $4.77^{\mathrm{L}}$ & $2.5 \pm 0.26^{\mathrm{a}}$ & $9.04^{\mathrm{L}}$ \\
\hline FF & $0.83 \pm 0.06^{\mathrm{a}}$ & $13.83^{\mathrm{L}}$ & $0.82 \pm 0.04^{\mathrm{a}}$ & $20.5^{\mathrm{H}}$ \\
\hline $\mathrm{PR}$ & $10.46 \pm 1.30^{\mathrm{a}}$ & $8.04^{\mathrm{L}}$ & $10.64 \pm 0.82^{\mathrm{a}}$ & $12.98^{\mathrm{L}}$ \\
\hline
\end{tabular}

Note: Different letters indicate significant differences between the study sites (t-test, $\mathrm{p}<0.05)$. LL $=$ lamina length; $\mathrm{PL}=$ petiole length; LW = lobe width; WP = length of lamina at largest width; $\mathrm{NSV}=$ number of secondary veins; $\mathrm{AV}=$ angle between the primary and secondary veins; $\mathrm{LA}=$ leaf area; $\mathrm{CL}=$ circumference of leaves; $\mathrm{AR}=$ aspect ratio of leaf; $\mathrm{FF}=$ form factor; $\mathrm{PR}=$ perimeter ratio of diameter; $\mathrm{L}=$ low; $\mathrm{H}=$ high

Ten RAPD primers were selected based on the previous studies of Lee et al. (1999) and Yulita and Partomihardjo (2011) (see Table 1). The genetic diversity of $D$. aromatica populations was then assessed by interpreting the resulting DNA electropherogram and analyzing the data using POPGENE 32 version 1.31 (Yeh et al. 1999). Furthermore, NTedit version 1.07c (Jamshidi and Jamshidi 2011) and NTSYS version 2.0 (Rohlf 2008) software were used to generated dendrogram derived from UPGMA cluster analysis using Dice coefficient of similarity of RAPD marker. The number of genetically homogeneous populations $(\mathrm{K})$ was estimated in STRUCTURE version 2.3.4 (Pritchard et al. 2000) using a Bayesian model-based clustering method. A burn-in of 20,000 iterations was performed followed by 100,000 Markov chain Monte Carlo iterations. Results were then collated using STRUCTURE HARVESTER (Earl and von Holdt 2012), which showed that the model was run for $\mathrm{K}$ values ranging from 1 to 8 , with five replications for each $\mathrm{K}$ value.

\section{Vegetation analysis}

Vegetation was sampled using systematic sampling along transects (100 m long, $20 \mathrm{~m}$ wide) from random start points. Three transects were established in the natural forests at an altitude of $0-250 \mathrm{~m}$ above sea level (asl) or $>250 \mathrm{~m}$ asl, whereas two transects were created in the community-owned forest. Nested plots of varying size (20 $\times 20 \mathrm{~m}, 10 \times 10 \mathrm{~m}, 5 \times 5 \mathrm{~m}$, and $2 \times 2 \mathrm{~m}$ ) were established within each of the transects (Soegianto 1994). The distribution pattern of $D$. aromatica was then determined by calculating Morisita's index of dispersion (Krebs 1989).

\section{RESULTS AND DISCUSSION}

\section{Morphological variation of the leaves}

The leaves of $D$. aromatica trees growing in the community-owned forest at Barus had significantly greater lamina lengths, length of the widest leaves to the leaf base, and maximum leaf widths than those of trees growing in the natural forest at Danau Paris (Table 2), with the maximum leaf widths of trees from both locations matching the range of 3-6 cm observed by Lemmens and Bunyapraphatsara (2003). By contrast, the petiole length was significantly longer in trees in Danau Paris than that in trees in Barus. Furthermore, trees in Danau Paris had significantly more secondary veins in their leaves and a considerably greater angle between the veins than those in Barus. There were no significant differences in any of the other traits measured. Furthermore, leaves from both locations had similar form factors (FFs) of $<1$, indicating that they were not round ( $\mathrm{Wu}$ et al. 2007), and leaf roundness was categorized as highly elliptical.

Diversity was assessed by calculating the coefficient of variance $(\mathrm{CV})$. Based on a $\mathrm{CV}$ value of $>20 \%$ indicating high diversity (Suhartini and Tintin 2010), only the angle between the veins and form factor of leaves in the Barus population exhibited high levels of variation (Table 2). This general lack of variation in leaf morphology is likely due to the short distance between sampling locations and the low level of genetic variation between subpopulations.

\section{Genetic diversity within populations}

There was little difference in the observed number of alleles $\left(\mathrm{N}_{\mathrm{a}}\right)$, the effective number of alleles $\left(\mathrm{N}_{\mathrm{e}}\right)$, percentage of loci polymorphic (PLP), expected heterozygosity $\left(\mathrm{H}_{\mathrm{e}}\right)$, and Shannon's information index $(I)$ between populations of D. aromatica growing in Danau Paris and Barus (Table 3). However, based on $\mathrm{H}_{e}$, PLP, and $\mathrm{N}_{\mathrm{a}}$, the Barus population had the highest genetic diversity, whereas the Singkohor population had the lowest genetic diversity. These differences cannot be explained by differences in altitude because $\mathrm{H}_{\mathrm{e}}$ is not affected by altitude and Singkohor, Danau Paris, and Barus are located at altitudes of 56, 200, and $46 \mathrm{~m}$ asl., respectively. Similarly, Srihari et al. (2013) found no correlation between genetic variation of Hippophae spp. and altitude. 
Table 3. Genetic diversity parameters in populations of Dryobalanops aromatica at the three study sites

\begin{tabular}{lcccccc}
\hline Population & $\mathbf{n}$ & $\mathbf{P L P}(\mathbf{\%})$ & $\mathbf{N}_{\mathbf{a}}$ & $\mathbf{N}_{\mathbf{e}}$ & $\mathbf{H}_{\mathbf{e}}$ & $\boldsymbol{I}$ \\
\hline Singkohor & 7 & 55.5600 & 1.5556 & 1.2973 & 0.1760 & 0.2686 \\
Danau Paris & 23 & 80.5600 & 1.8056 & 1.3250 & 0.2066 & 0.3271 \\
Barus & 30 & 88.8900 & 1.8889 & 1.3365 & 0.2134 & 0.3408 \\
Mean & 20 & 75.0033 & 1.7500 & 1.3196 & 0.1987 & 0.3122 \\
\hline Note: $\mathrm{n}=$ number of individual, PLP = percentage of loci \\
polymorphic, $\mathrm{N}_{\mathrm{a}}=$ observed number of alleles, $\mathrm{N}_{\mathrm{e}}=$ effective \\
number of alleles,, $\mathrm{H}_{\mathrm{e}}=$ expected heterozygosity, $I=$ Shannon's \\
information index.
\end{tabular}

Table 4. Genetic distance based on Nei's unbiased measures and geographical distance $(\mathrm{km})$

\begin{tabular}{llll}
\hline Population & Singkohor & Paris Danau & Barus \\
\hline Singkohor & $*$ & $27.8^{\mathrm{G}}$ & $64.4^{\mathrm{G}}$ \\
Paris Danau & $0.0363^{\mathrm{g}}$ & $*$ & $36.3^{\mathrm{G}}$ \\
Barus & $0.0534^{\mathrm{g}}$ & $0.0478^{\mathrm{g}}$ & $*$ \\
\hline
\end{tabular}

Note: $\mathrm{g}=$ genetic distance, $\mathrm{G}=$ geographical distance.

The mean PLP value for D. aromatica was $75.00 \%$. By contrast, other species in Dipterocarpaceae have been found to have lower PLPs, including Vatica guangxiensis (32.46\%; Li et al. 2002), Dipterocarpus retusus and D. hasseltii $(56.06 \%$ and $63.63 \%$, respectively; Sumiyati et al. 2009), and Parashorea chinensis (20.80\%; Li et al. 2005) using RAPD markers. Yulita and Partomiharjo (2011) argued that in RAPD analyses, the larger the number of individuals in a sample, the more alleles there will be and thus the higher the number of polymorphic loci.

\section{Genetic diversity between populations}

Comparison of the genetic and geographical distances between the three study populations indicates that the higher the distance between locations, the higher the genetic distance (Table 4). Similarly, Schnabel and Hamrick (1990) and Alpert et al. (1993) concluded that genetic distance is positively correlated with geographic distance. Julisaniah et al. (2008) stated that crosspollination between plants with a small genetic distance or similar relationship increases homozygosity, whereas cross-pollination between plants with a large genetic distance or distant relationship increases heterozygosity. Therefore, this information will be useful when formulating conservation strategies for $D$. aromatica, particularly for the production of high-quality seeds.

Cluster analysis showed that the individuals in each population were widely spread (Figure 2). This is presumably due to the three populations having a close relationship or low genetic diversity among them $(\mathrm{Dst}=0.0285$, Table 5$)$. The total genetic diversity in all populations $(\mathrm{Ht})$ was 0.2272 , whereas the average genetic diversity within populations (Hs) was 0.1987 (Table 5). By contrast, the genetic diversity between populations (Dst) was 0.0285 , which is much lower than both Ht and Hs. Genetic differentiation between the populations (Gst) was 12.57\%, which is considered intermediate, whereas gene flow $(\mathrm{Nm})$ between the populations was 3.4787 , which reflects the mixed pollination system of $D$. aromatica that is facilitated by insects, wind, and water (Hamrick and Godt 1990). Similarly, Lee et al. (2000) using allozyme markers showed that $D$. aromatica growing in Peninsular Malaysia had an $\mathrm{Nm}$ of 6.6900 and pollination assisted by insects, water, and wind. This contrasts with the Nm value of 1.8424 for Dipterocarpus littoralis, in which pollination is only assisted by insects (Yulita and Partomihardjo 2011), indicating that insects are the primary pollinators of Dipterocarp species. Several species of bee have been identified as pollinators of $D$. aromatica, including Apis melliphera (Harata et al. 2012), A. dorsata ${ }_{2}$ and A. indica (Appanah 1985; Ashton 1988).

\section{Genetic structure of the populations}

According to STRUCTURE HARVESTER, the genetic structure of $D$. aromatica varied considerably between the Singkohor, Danau Paris, and Barus populations (Figure 3). Analysis of the genetic patterns indicated that the highest value of $\Delta \mathrm{K}$ was obtained when $\mathrm{K}=2(\Delta \mathrm{K}=412.00)$. Therefore, STRUCTURE analysis divided the $D$. aromatica populations into two clusters: the natural forests (Singkohor and Danau Paris) and the community-owned forest (Barus).

\section{Species diversity and spatial distribution}

Seedlings, saplings, and trees in the natural forest at Danau Paris had high levels of species diversity $\left(\mathrm{H}^{\prime}>3\right)$, whereas the poles had intermediate levels (Table 6). By contrast, all growth stages, except seedlings, had intermediate levels of species diversity $\left(\mathrm{H}^{\prime}=2-3\right)$ in the community-owned forest at Barus.

Both sites had dominance (C) values of $<0.5$ (Table 6), indicating that no dominant species was present. $\mathrm{C}$ values are used to determine the concentration and distribution of dominant species, being higher when there is a higher abundance of one particular species and lower when several species are codominant. In addition, $\mathrm{C}$ values can be used to determine the distribution pattern of a species, with a value of $<1$ indicating that the population has a clumped distribution.

Table 5. The average genetic diversity of Dryobalanops aromatica in Sumatra, Indonesia and Peninsular Malaysia and Dipterocarpus littoralis in Central Java, Indonesia based on the analysis of Nei (1978)

\begin{tabular}{llcccccc}
\hline Species & Site & Ht & Hs & Gst & Dst & Nm & Reference \\
\hline Dryobalanops aromatica & Aceh Singkil and North Sumatra & 0.2272 & 0.1987 & 0.1257 & 0.0285 & 3.4787 & This study \\
D. aromatica & Peninsular Malaysia & 0.5550 & 0.5350 & 0.0360 & 0.0385 & 6.6900 & Lee et al. 2000 \\
Dipterocarpus littoralis & Nusakambangan, Central Java & 0.1958 & 0.154 & 0.2135 & 0.0418 & 1.8424 & Yulita and \\
& & & & & & & Partomihardjo 2010 \\
\hline
\end{tabular}

Note: $\mathrm{Ht}=$ genetic diversity in all populations, $\mathrm{Hs}=$ genetic diversity within the population, Gst $=$ genetic differentiation, Dst $=$ genetic diversity between populations; $\mathrm{Nm}=$ gene flow 


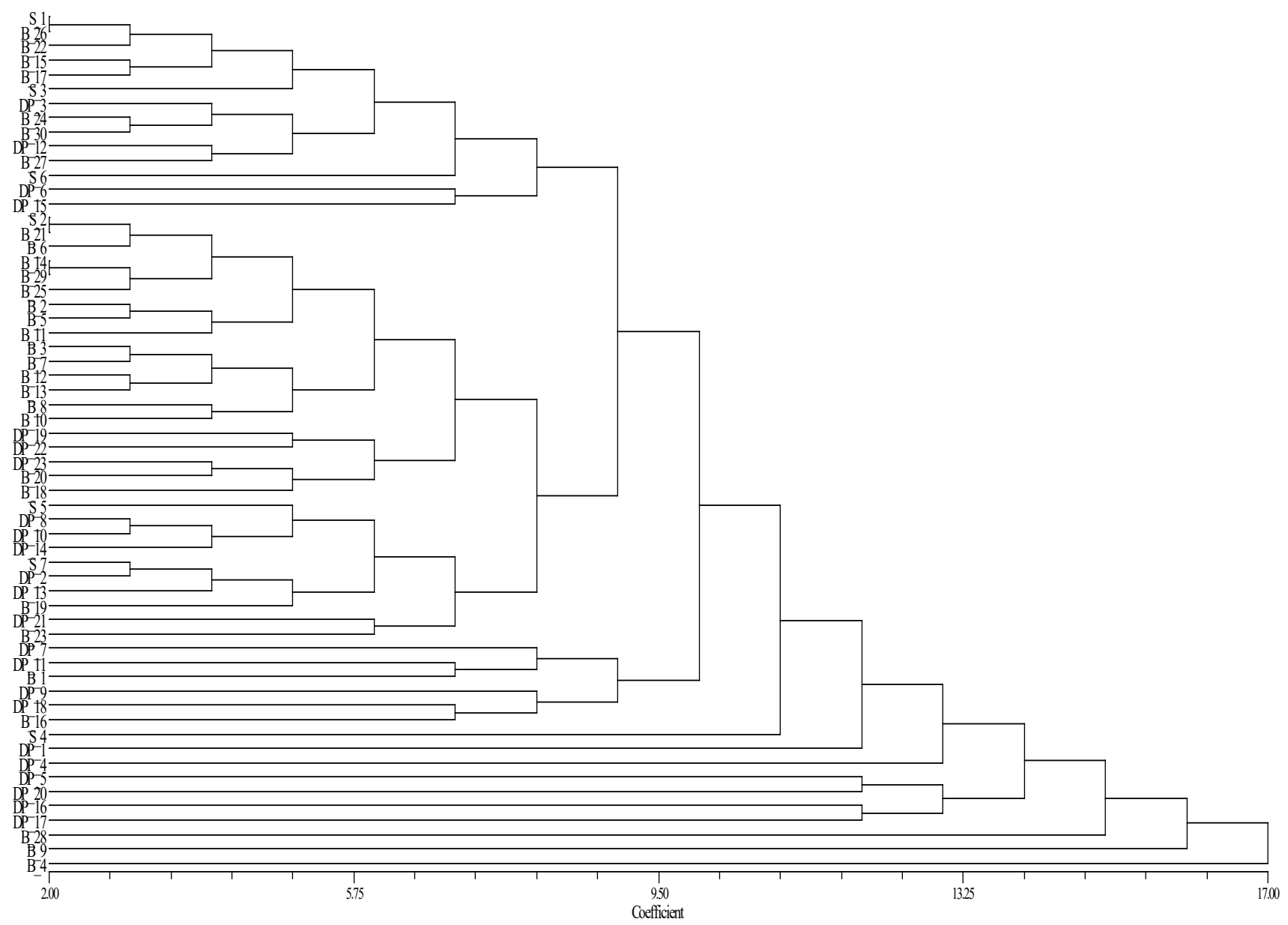

Figure 2. UPGMA dendrogram of Dryobalanops aromatica from the three study sites in Sumatra, Indonesia ( $\mathrm{S}=\mathrm{Singkohor}$, $\mathrm{B}=\mathrm{Barus,}$ $\mathrm{DP}=$ Danau Paris) based on RAPD profiles

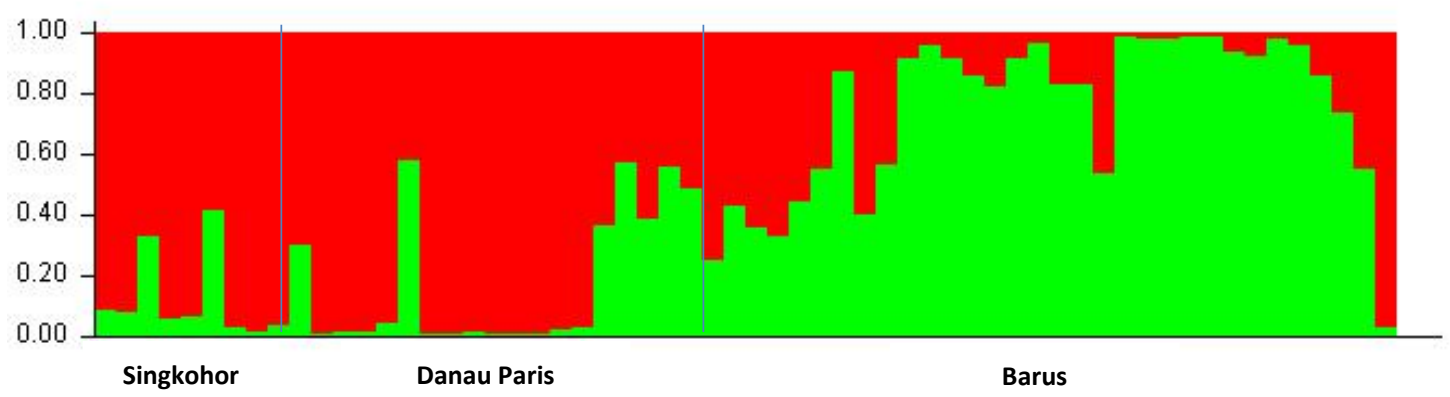

Figure 3. Population structure of Dryobalanops aromatica at the three study sites in Sumatra, Indonesia. The populations were separated into two clusters: Singkohor and Danau Paris (red), and Barus (green)

Table 6. Species diversity and dominance indices at Danau Paris and Barus, Sumatra, Indonesia

\begin{tabular}{lcccccccc}
\hline & \multicolumn{3}{c}{ Danau Paris } & \multicolumn{3}{c}{ Barus } \\
\cline { 2 - 9 } & Seedlings & Saplings & Poles & Trees & Seedlings & Saplings & Poles & Trees \\
\hline $\mathrm{H}^{\prime}$ & 3.8125 & 3.2049 & 2.8927 & 3.0370 & 3.0364 & 2.1292 & 2.8721 & 2.9781 \\
$\mathrm{C}$ & 0.0729 & 0.0888 & 0.0944 & 0.1197 & 0.1022 & 0.1775 & 0.0820 & 0.0850 \\
\hline
\end{tabular}

Note: $\mathrm{H}^{\prime}=$ Shannon's diversity index; $\mathrm{C}$ = Simpson's dominance index. 
Morisita's index of dispersion also indicated that the $D$. aromatica populations at both Danau Paris and Barus had clumped distributions (ip $<1$; Table 7). Barbour et al. (1987) stated that plant species tend to have clumped distributions because they reproduce by seeds that fall close to the parent plant, and Sofiah et al. (2013) demonstrated that clumped distribution patterns could be generated in populations with high and low abundances. Both sites appeared to have a higher frequency and density of $D$. aromatica than other species in each growth stage, despite D. aromatica not having flowered in the last three years, supporting Lee (2000) argument that there is no correlation between the density of mature trees in a population and their level of flowering.

Dryobalanops aromatica was the most dominant species in the natural and community-owned forests based on the abundance of species from seedlings to trees. The importance value index (IVI) is used to describe the relative dominance of a species based on abundance, with a value of $>10 \%$ indicating that a particular species is associated with other species (Sofiah et al. 2013). D. aromatica was associated with different species at each site in the seedling and sapling stages (Table 8) as a result of differences in altitude, microclimate, soil type, and surrounding communities between the sites. However, poles of D. aromatica were associated with Shorea spp. (meranti putih) and Xanthophyllum excelsum at both locations. In all growth stages (seedling to tree), the IVI of D. aromatica was the highest at Barus. This is likely due to this site having appropriate conditions (e.g., altitude, rainfall, and soil) for $D$. aromatica growth; Barus has clay soil texture and lies at an altitude of $46 \mathrm{~m}$ a.s.l., whereas Danau Paris has a dusty, clayey soil texture and is located at an average altitude of $230 \mathrm{~m}$ a.s.l. However, the factors that will have the most significant effect on the IVI at each site are human-related. In the community-owned forest at Barus, all species of commercial plants are well maintained until they reach maturity, resulting in Artocarpus rigidus, Aporusa aurita, Gluta rengas, and Shorea spp. being most closely associated with $D$. aromatica. By contrast, in the natural forest at Danau Paris, there is no human intervention, resulting in $D$. aromatica being the most closely associated with Shorea spp., Koompassia malaccensis, Sterculia macrophylla, Sindora leiocarpa, and Barringtonia sp.

Table 7. Dispersion indices of Dryobalanops aromatica at Danau Paris and Barus

\begin{tabular}{lcccccccc}
\hline & id & $\boldsymbol{\Sigma} \mathbf{x}$ & $\boldsymbol{\Sigma}^{\mathbf{2}}$ & $\mathbf{( \Sigma \mathbf { x } ) ^ { \mathbf { 2 } }}$ & $\mathbf{M}_{\mathbf{u}}$ & $\mathbf{M}_{\mathbf{c}}$ & ip & Pattern \\
\hline Danau Paris & 1.23 & 64.00 & 229.00 & 4096.00 & 0.79 & 1.27 & 0.43 & Clumped \\
Barus & 1.13 & 32.00 & 118.0 & 1024.00 & 1.13 & 2.09 & 0.06 & Clumped \\
\hline
\end{tabular}

Note: id = Fisher's index of dispersion, $\Sigma \mathrm{x}=$ sum of the number of individuals of a species in a square, $\Sigma \mathrm{x}^{2}=$ sum of the squares of the number of individuals of a species, $\mathrm{M}_{\mathrm{u}}=$ uniform index, $\mathrm{M}_{\mathrm{c}}=$ clumped index, ip = Morisita's index of dispersion

Table 8. Plants associated with Dryobalanops aromatica at Danau Paris and Barus

\begin{tabular}{|c|c|c|c|c|}
\hline Growth stage & Danau Paris & IVI & Barus & IVI \\
\hline \multirow[t]{3}{*}{ Seedling } & Dryopteris immersa $\square$ & 15.92 & Dryobalanops aromatica & 40.95 \\
\hline & Aspelnium sp. & 13.77 & Piper miniatum Blume & 11.28 \\
\hline & Nephrolepis hirsutula & 19.48 & Flacourtia rukam & 16.25 \\
\hline \multirow[t]{5}{*}{ Sapling } & Dryobalanops aromatica & 34.30 & Hevea brasiliensis & 36.59 \\
\hline & Sindora leiocarpa & 25.80 & Dryobalanops aromatica & 47.72 \\
\hline & Barringtonia sp. & 11.81 & Aporusa aurita & 21.13 \\
\hline & & & Agrostictachys sessilifolia & 16.59 \\
\hline & & & Artocarpus rigidus & 33.18 \\
\hline \multirow[t]{7}{*}{ Pole } & Xanthophyllum excelsum & 11.61 & Shorea spp. & 17.93 \\
\hline & Teysmaniodendron sp. & 15.43 & Dryobalanops aromatica & 51.07 \\
\hline & Shorea spp. & 15.47 & Artocarpus rigidus & 26.61 \\
\hline & Barringtonia sp. & 12.77 & Xanthophyllum excelsum & 28.98 \\
\hline & Sindora leiocarpa & 14.35 & Gluta renghas & 40.17 \\
\hline & Sterculia macrophylla & 49.54 & Artocarpus integer & 16.55 \\
\hline & Dryobalanops aromatica & 51.06 & & \\
\hline \multirow[t]{6}{*}{ Tree } & Sterculia macrophylla & 10.41 & Shorea spp. & 18.33 \\
\hline & Shorea spp. & 19.84 & Dryobalanops aromatica & 69.19 \\
\hline & Dryobalanops aromatica & 66.09 & Artocarpus rigidus & 15.24 \\
\hline & Nauclea sp. & 17.39 & Xanthophyllum excelsum & 28.72 \\
\hline & Barringtonia sp. & 23.37 & Gluta renghas & 21.66 \\
\hline & Koompassia malaccensis & 32.21 & & \\
\hline
\end{tabular}


In conclusion, $D$. aromatica had an intermediate level of genetic diversity $\left(\mathrm{H}_{\mathrm{e}}=0.1987\right)$, with the Barus population having the highest levels $\left(\mathrm{H}_{\mathrm{e}}=0.2134\right)$ and the Singkohor population having the lowest levels $(\mathrm{He}=$ $0.1760)$. D. aromatica also had an intermediate level of genetic differentiation $(\mathrm{Gst}=12.57 \%)$, with no evidence of the three populations being genetically segregated. This species had clumped spatial distribution patterns at Danau Paris and Barus (ip $=0.06$ and 0.43 , respectively). These findings indicated that in situ management in combination with enrichment planting in areas with a low abundance of plants using locally sourced seeds or other plant materials would be an effective genetic conservation strategy for $D$. aromatica.

\section{ACKNOWLEDGEMENTS}

The authors thank Budi Basa Siregar, Head of Forestry and Plantation Department of Central Tapanuli, and $\mathrm{Mr}$. Basri, Head of Forestry and Plantation Department of Aceh Singkil, for permission to enter and collect experimental leaf material and soil. High appreciation goes to Sujlizar and Silaban for their assistance during sampling in the natural and community-owned forests. The. study was partly supported by International Research Collaboration 2018 (PKLN Scheme Ristekdikti No: 1580/IT3.11/PN/ 2018) entitled "Adaptive Genetic Divergence on Dryobalanops aromatica Growing in Sumatran Tropical Peat Swamp Forests".

\section{REFERENCES}

Alpert P, Lumaret RD, Giusto F. 1993. Population structure inferred from allozyme analysis in the clone herb Fragaria chiloensis (Rosaceae). Am J Bot 80: 1002-1006.

Appanah S. 1985. General flowering in the climax rain forests of Southeast Asia. J Trop Ecol 1: 225-240.

Anwar A. 2015. Variations in leaf morphology and ITS2 sequences in jelutung darat (Dyera costulata) and jelutung rawa (Dyera polyphylla). [Thesis]. Institut Pertanian Bogor, Bogor, Indonesia.

Aritonang KV, Siregar IZ, Yunanto T. 2007. Manual analisis genetik tanaman hutan di Laboratorium Silvikultur Fakultas Kehutanan Institut Pertanian Bogor. Fakultas Kehutanan IPB, Bogor, Indonesia. [Indonesian]..

Ashton PS. 1988. Dipterocarp biology as a window to the understanding of tropical forest structure. Ann Rev Ecol. Syst 19: 347-370.

Barbour GM, Burk JK, Pitts WD. 1987. Terrestrial plant ecology 2nd Edition. Benyamin-Cumming Publishing. Inc. Reading. Maine, New York.

Dwiyanti FG, Kamiya K, Harada K. 2014. Phylogeographic structure of the commercially important tropical tree species, Dryobalanops aromatica Gaertn. f. (Dipterocarpaceae) revealed by microsatellite markers. Reinwardtia 14 (1): 43-51.

Dwiyanti FG, Chong L, Diway B, Lee YF, Siregar IZ, Subiakto A Kamiya K, Ninomiya I, Harada K. 2015. Population genetic diversity in the genus Dryobalanops aromatica Gaertn. F. (Dipterocarpaceae) based on nuclear microsatellite markers. J Sustain 3 (1): 12-20.

Earl DA, von Holdt BM. 2012. Structure Harvester: A website and program for visualizing structure output and implementing the Evanno method. Conserv Genet Resour 4: 359-361.

Gusmailina. 2014. Borneol - future potential of essential oils. Pros Sem Nas Masy Biodiv Indon 1 (2): 259-264.

Hamrick JL, Godt MJ. 1990. Allozyme diversity in plant species. In: Brown AHD, Clegg MT, Kahler AL, Weir BS (eds).Plant Population
Genetics, Breeding, and Genetic Resources. Sinauer Associates Inc., Sunderland, Massachusetts, USA, pp. 43-63.

Harata T, Nanami S, Yamakura T, Matsuyama S, Chong L, Diway BM, Tan S, Itoh A. 2012. Fine-scale spatial genetic structure of ten dipterocarp tree species in a Bornean Rain Forest. Biotropica 44: 586594

Jamshidi S, Jamshidi S. 2011. NTSYSpc 2.02e Implementation in molecular biodata analysis (clustering, screening, and individual selection). Proceedings of 4th International Conference on Environmental and Computer Science 19 (2011):165-169

Julisaniah NI, Sulistyowati L, Sugiharto AN. 2008. Analisis Kekerabatan Mentimun (Cucumis sativus L.) menggunakan Metode RAPD-PCR dan Isozim. Biodiversitas 9: 99-102.

Kaur A, Ha C, Jong K, Sands VE, Chan HT, Soepadmo E, Ashton PS. 1978. Apomixis may be widespread among trees of the climax rainforest. Nature 271: 440-442.

Krebs JC. 1989. Ecological Methodology. 2nd ed. Harper Collins, New York.

Kremer A, Dupouey J, Deans JD, Cottrell J, Csaikl U, Finkeldey R, Espinel S, Jensen J, Kleinschmidt J, Van Dam B, Ducousso A, Forrest I, de Heredia L, Lowe AJ, Tutkova M, Munro RC, Steinhoff S, Badeau V. 2002. Leaf morphological differentiation between Quercus robour and Quercus petraea is stable across western European mixed oak stands. Ann For Sci 59 (7): 777-787.

Lee SL, Wickneswari R, Mahani MC, Zakri AH. 1999. Comparative genetic diversity studies of Shorea leprosula (Dipterocarpaceae) using RAPD and allozyme markers. J Trop For Sci 13: 202-215.

Lee SL, Ang KC, Norwati M. 2000. Genetic diversity of Dryobalanops aromatica Gaertn. F (Dipterocarpaceae) in Peninsular Malaysia and its pertinence to genetic conservation and tree improvement. For Gen 7: 211-219.

Lee SL. 2000. Mating system parameters of Dryobalanops aromatica Gaertn. f. (Dipterocarpaceae) in three different forest types and a seed orchard. Heredity 85 : 338-345.

Lemmens RHMJ, Bunyapraphatsara N. 2003.Plant Resources of SouthEast Asia No 12: Medicinal and Poisonous Plants 3. Backhuys Publisher, Leiden.

Li QM, Xu ZF, He TH. 2002. A preliminary study on conservation genetics of endangered Vatica guangxiensis (Dipterocarpaceae). Acta Botanica Sinica 44 (2): 246-249.

Li QM, He TH, Xu ZF. 2005. Genetic evaluation of the efficacy of in situ and ex situ conservation of Parashore chinensis (Dipterocarpaceae) in southwestern China. Biochem Genet 43: 387-406.

Minitab. 2010. Minitab 16 statistical software. Minitab Inc., State College, Pennsylvania, PA

Nei M. 1978. Estimation of average heterozygosity and genetic distance from a small number of individuals. Genetics 89: 583-590.

Nguyen MT, Vu DD, Nguyen MD, Vu DG. 2014. Genetic diversity in the natural populations of Dipterocarpus costatus (Dipterocarpaceae). Res J Biotech 9: 14-19.

Pritchard JK, Stephen M, Donnelly P. 2000. Inference of population structure using multilocus genotype data. Genetics 155: 945-959.

Rohlf FJ. 2008. Numerical Taxonomy and Analysis System (NTSYSpc) Version 2.0. Department of Ecology and Evolution State University of New York, New York. $\square$

Schnabel A, Hamrick JL. 1990. Organization of genetic diversity within and among populations of Gleditsia triacanthos (Leguminosae). Am J Bot 77: 1060-1069.

Soegianto A. 1994. Ekologi kuantitatif. Surabaya Usaha Nasional, Indonesia. [Indonesian] $\square$

Sofiah S, Setiadi D, Widyatmoko D. 2013. Distribution pattern, association, and abundance of bamboo in plants community in Mount Baung Natural Tourism Park East Java. Berita Biologi 12 (2): 239247.

Srihari JM, Verma B, Kumar N, Chahota RK, Singh V, Rathour R, Singh SK, Sharma SK, Sharma TR. 2013. Analysis of molecular genetic diversity and population structure in sea buckthorn (Hippophae spp L.) from north-western Himalayan region of India. J Med Plant Res 7: 3183-3196.

Suharsono, Utut W. 2012. Penuntun praktikum pelatihan teknik dasar pengklonan gen. Pusat Penelitian Sumberdaya Hayati dan Bioteknologi Institut Pertanian Bogor. Institut Pertanian Bogor, Bogor, Indonesia. [Indonesian]. 
Suhartini T. 2010. Keragaman karakter morfologis plasma nutfah spesies padi liar (Oryza spp.). Buletin Plasma Nutfah 16 (1): 17-28. [Indonesian]

Sumiyati D, Dwiyanti FG, Istomo I, Siregar IZ. 2009. Growth and genetic variation evaluation of mountain palahlar and palahlar based on RAPD marker. J Trop For Manag 15 (3): 109-116. [Indonesian]

Tsumura Y. 2011. Gene flow, mating systems, and inbreeding depression in natural populations of tropical trees. In: Managing the Future of Southeast Asia's Valuable Tropical Rainforests, Springer, Dordrecht.

Weising K, Nybon H, Wolff K, Kahl G. 2005. DNA Fingerprinting in Plants: Principles, Methods, and Applications. CRC Press, Boca Raton, FL.

Wibowo A, Ahmat N, Hamzah AS, Sufian AS, Ismail NH, Ahmad R, Jaafar FM, Takayama H. 2011. Malaysianol A, a new trimer resveratrol oligomer from the stem bark of Dryobalanops aromatica. Fitoterapia 82 (4): 676-681

Wu SG, Bao FS, Xu EY, Wang YX, Chang YF, Xiang QL. 2007. A leaf recognition algorithm for plant classification using probabilistic neural network. 2007 IEEE International Symposium on Signal Processing and Information Technology (ISSPIT) 11-16. DOI: 10.1109/ISSPIT.2007.4458016

Yeh FC, Yang R, Boyle T. 1999. POPGENE, Microsoft Window-based Freeware for Population Genetic Analysis. Version 1.31, University of Alberta, Edmonton, Canada.

Yulita KS, Partomihardjo T. 2011. Population genetic diversity of Pelahlar (Dipterocarpus littoralis (B1.) Kurz) in Nusakambangan Island based on enhanced Random Amplified Polymorphic DNA. Berita Biologi 10 (4): 541-548. 